\title{
Feltbreve.
}

\author{
Kære Venner! \\ Rusland, den 16. 3. 1917.
}

Først maa I undskylde, at jeg skriver saa sjældent. Men for det forste har man ikke altid saa god Lejlighed, og for det andet har man ikke meget godt at skrive om, og sandheden maa man jo heller ikke fortælle.

Ja, det er sørgelige Forhold at leve under i saa lang en Tid. Og saa denne forfærdelige haarde Vinter, som vi har haft i Aar. Ja, man skulde virkelig undres over, at vi kan gaa det igennem. Og markeligt nok, man er i Grunden raskere og mindre forkølet her end hjemme. Men man mærker dog, at det gaar ned ad Bakke. Dette ser man rigtig paa de Saarede, ved det allermindste falder de straks i Afmagt. Og dette er jo heller ikke til at undre sig over, vi faar ingen Menneskefode mere og lever alt for flovt efter det, vi skal gaa igennem. $\mathrm{Nu}$, lad mig ikke gaa narmere ind herpaa, I kan jo nok tanke Eder, hvordan det ser ud her hos os.

Saa er der en Ting endnu, som jeg lige vil omtale. Nu er de jo slemt i Gang med det sjette Krigslaan. Sidste Gang var de jo ogsaa hos os, og de fleste af os tegnede ogsaa efter Evne, jeg og mine Landsmand naturligvis ikke. $\mathrm{Nu}$ denne Gang lod Kompagniføreren mig komme til sig en Middag, og han bearbejdede mig slemt $i$ en god Time. Nu vil jeg kun foreløbig fortalle, at vi skiltes denne Dag 
som Vermer, i det mindste sagde han det. - Men nu har han sagt til min Inderofficer, at vi skulde bort til Nyformationer med den første Transport. - Dette er nu nok kun en af de bekendte tyske Trusler, jeg tror nok, at han har andre $i$ Kompagniet, som han hellere vil af med end os. Betingelserne var jo, efter hvad han forklarede, gode. $\mathrm{Og}$ en Ting er det, at den, der tegner en $23-4$ Tusind Mark faar straks en 3 \& Iger's (orlov ekstra og en god Trykpost dertil. I)er er jo enkelte, som gaar ind derpaa.

Her blev jeg afbrudt i Aftes, da der atter blev gjort Allarm. Ja, luusserne lader os ikke rigtig mere $\mathrm{i}$ ho, og let hele tegner til, at det rigtig skal gaa los i Aar jgen. Nu lad os haabe det bedste. Jeg vil saa slutte denne Gang med de venligste Hilsener til Eder alle fra Eders V'en.

Kare Ven!

Rusland, den 28. 3. 1917.

Vil endnu i Aften sende dig et Par Ord og det endia de sidste her fra dette Kompagni. Og nu skal du hore, hrad jeg har maattet gaa igennem $\mathbf{i}$ den sidste Tid. Sim du jo godt ved, arbejder de jo svært med det sjette Krigslaan i denne Tid. Hvor de nu har erfaret, at jeg var sardeles godt stillet hjemme og nok kunde tegne en temmelig sum, ved jeg ikke. To (iange lod Kompagniforelen mig kalde, men kunde intet udrette. Saa sendte han nig til Bataillonen og Lagen, men endskont jeg vidste, at hvis jer gik udenom det, havde det slemme Folger, kunde jeg ikke gaa med til saadan noget. Kort sagt, jeg afslog det, og du ved jo, at jeg mangen Gang kan blive ikke saa lidt hidsig, og sagde ham tilsidst Grunden, fortalte om Forholdene oppe hos os osv. 
Og nu skal I høre Enden af Visen. Først vil jeg sige, at jeg er meget forknyt, jeg synes at jeg overfor min Kone har handlet forkert og kan ikke finde Ro. Det er midt om Natten, sove kan jeg ikke. $\mathrm{Nu}$, jeg kommer jo lidt bort fra Sagen.

I Morgen tidlig forlader jeg Kompagniet og skal melde mig hos "Stosstruppen", det vil sige en Trop, som altid stormer og kommer hen paa de varste Steder. Hvad siger du dertil, er det ikke mere end nederdrægtig! Det har jo været slemt denne Gang at faa de Feltgraa til at tegne, og nu skal dette vel vare til Skræk og Advarsel for de andre. Jo, jeg havde Lyst til at fortælle mere endnu, men jeg tor ikke. Saasnart jeg nu har naaet mit Bestemmelsessted, skar du nok høre fra mig. Kanske konmer jeg til Tyskland og bliver uddannet. Skriv mig et Par Ord, saasnart du faar min nye Adresse. Og Tak for alt, hvad du har været for mig.

Modtag saa hermed alle baade gamle og unge de bedste Hilsener fra

Lev vel og paa Gensyn!

J. P.

Fortæl endnu intet herom til min Kone. Hum skal endnu intet vide herom, hvad de egentlig har for med mig. Og kanske kan det lykkes for nig at faa Orlov.

\section{Kære Ven!}

Rusland, den 1. April 1917.

Først vil jeg meddele dig, at jeg efter Omstændighederne har det ganske godt og er sund og rask. Dernæst, som du ogsaa saa paa min' Adresse, er jeg kommen bort fra 90 . Grunden skal jeg nu i al Kort- 
hed fortalle dig, og du kan saa selv dømme, som du vil. Kort og godt, jeg vilde jo ingen Krigslaan tegne. Først blev jeg taget med gode Ord og dernæst med Trusler, og dem har de nu opfyldt. Baade overfor Kompagnifeldwebelen, Kompagniføreren og Stabslægen nægtede jeg det. Sidste spurgte mig tilsidst, om jeg var en Slesviger eller en Dansker. Jeg gav det Svar, at Dannark endnu ikke var glemt hos os. En Landsmand mere, $B$. fra Tandselle, havde de ogsaa for. $O g$ de vidste bestemt, at vi to var godt stillede og let kunde tegne 3-5000 Mark. Vel at mærke gik det hele ikke saa let, som jeg her fortæller det, men jeg haaber at komme paa Orlov, saasnart vi er uddannede. B. og jeg blev af Kompagniføreren bestemt til at forlade Kompagniet, men B. er en Mand paa 39 Aar og ser meget afkræftet og svag ud. Dette har vel i sidste Øjeblik gjort ham bange, og i Stedet for ham blev en anden bestemt fra Lothringen, skønt der havde meldt sig 6 frivillige. Vi skal her uddannes til en Afdeling indenfor vor Division, som altid skal storme, naar der skal hentes et Stykke Grav, og ligeledes, naar Russerne har smidt vore ud af Graven.

$\mathrm{Vi}$ er ikke udrustede som Infanterister, hvordan kan jeg endnu ikke fortælle, da vi kun har været sammen i to Dage. Vi er 120 Mand, to fra hvert Kompagni i hele Divisonen. Heraf tæenker jeg nu, at I kan indse, at ogsaa her grider det Penge eller Livet.

Jeg tror nu nok, at vi har det meget bedre end Infanteristerne. Vi ligger altid bag i Etappen og kommer kun forud, naar der er noget løs. I hvert Fald er det meget værd at vare ude af Skyttegraven nu, da alt tør op. Nu nærmere herom med det første, jeg haaber, snart at høre et Par Ord fra dig, kære 
Ven. Vi har nu ogsaa endelig her i Rusland faaet Tøvejr. Kursuset, som vi skal gore med, varer til den 15. Maj, og saa er vi færdig til at gaa paa. Jeg vil kun tilføje, at jeg paa ingen Maade er forknyt herover. Jeg syntes ikke, at jeg kunde tegne Krigslaan, endskont jeg vidste, at jeg kom til at lide derfor. Haaber saa, at disse Linier finder Eder alle sunde og raske. Og vær saa hermed alle hilset paa det hjerteligste af Eders Ven J. P.

Lev vel og paa suarligt (iensyn!

Kære Ven!

Rusland, den 13. April 1917.

Min bedste Tak for dit Brev fra den 31. Marts. Havde da lige afsendt et Brevkort til dig et Par Dage for, som jeg haaber du har modtaget. Hvad Cigaren angaar skal jeg lige bemærke, at det jo er Hindenburg, der besorger os den Slags. I det mindste faar han altid skieldsordene for Kvaliteten. Ja, det ser daarligt ud hernede hos os nu, siden den 10. har de nu ogsaa aftrukket os betydeligt med Brødet. Dette Afdrag skal kun vare 10 Dage siger de, men vi kender jo de Herrer og ved, at de lover godt, men holder me ge t daarligt ord.

$\mathrm{Nu}$, jeg maa ellers ikke klage, saalinnge jeg er her. Hvad saa de stakler, der tramper ude i Graven. Det er saa slemit med Vandet nu, da al den Sne tor op, at de nxsten svummer baade inde og ude. Her lever vi jo som i Garnisonen. En stor, lys Bolig med Borde og Banke, Halmmadrasser, ja vi har her alt som i en Kaserne. (og særlig jeg har haft Lykken med nig lier. Naar de andre trisser med Eksersits og Apell, kan jeg sidle paa min Vogn og le af det 
hele. Jeg er nemlig bleven Kusk her ved denne hersens "Stosstrup«. Uddannelsen er egentlig en haard Skole at gaa igennem, baade i Praksis og Teori. Tænk dig i Lobet af 3 Uger teoretisk at lære alt ved et Maskingevær, Minekaster, Granatkaster, Flanmekaster. Og dertil kommer endnu Pistoler og alle de forskellige Haandgranater. Tjenesten er $\mathrm{i}$ Praksis kun kort, men meget stram, og en meget haard Disciplin hersker her.

Jeg vil saa lige meddele dig, at mine Landsmænd O. P. fra slyngsten og B. fra Als nu ogsaa er konımen bort fra 90. De er foreløbig kommen til Saarbrücken og bliver der tildelt Nyformationen. Heraf kan man se, hvordan de tvinger Folk til at tegne Krigslaan. Og bagefter hedder det saa, at enhver gav med Glæde, alt hrad de havde Evne til. Kanske kan de ogsaa have Lykken med sig.

Jeg har ot helt udmarket Levned her i Forhold til det $i \quad 7$. hompagni. Jeg bliver jo slet ikke uddannet, og naar do andle gaar forud og stormer, kan jeg blive her bag i Etapperne. Men de fleste her er ogsaa frivillige og har endnu Lyst til at gaa paa. $\mathrm{Nu}$, jeg har jo ikke noget med den at gøre, og det er absolut heller intet selskab for mig. Jeg staar ene her, ikke en Landsmand mere, dem savner jeg. O. P. og jeg havde nu i to lange og trange Aar delt godt og ondt med hinanden. I Vinter paa Feltvagt laa vi to sammen i $3^{1}$, Time i stark Artilleriill. $1 \mathrm{~g}$ i en saa stor Farestund er det nieget vard med en god Ven.

Hermed være I saa allesammen hilset paa det hjorteligste af Eders Ven J. P.

Lev vel og gid, at vi snart maa genses. 